\title{
Potential and limitations of the attribution of climate change impacts for informing loss and damage discussions and policies
}

\author{
Christian Huggel ${ }^{1} \cdot$ Dáithí Stone $^{2} \cdot$ Hajo Eicken $^{3}$ • \\ Gerrit Hansen $^{4}$
}

Received: 14 August 2014 / Accepted: 22 May 2015 / Published online: 17 June 2015

(C) Springer Science+Business Media Dordrecht 2015

\begin{abstract}
The issue of climate related loss and damage (L\&D) has re-emerged and gained significant traction in international climate policy in recent years. However, many aspects remain unclear, including how aspects of liability and compensation in relation with L\&D will be treated under the UNFCCC, human rights and environmental law. Furthermore, the type of scientific evidence required to link climate change impacts for each of these L\&D mechanisms needs to be clarified. Here we analyze to which degree different types of scientific evidence can inform L\&D discussions and policies. We distinguish between (i) L\&D observation, (ii) understanding causation, and (iii) linking L\&D to anthropogenic emissions through attribution studies. We draw on three case studies from Australia, Colombia and Alaska to demonstrate the relevance of the different types of evidence. We then discuss the potential and limitations of these types of scientific evidence, in particular attribution, for informing current L\&D discussions and policies. Attribution (iii) sets the highest bar, but also provides the most complete set of information to support adaptation, risk reduction and L\&D policies. However, rather than suggesting that attribution is a necessary requirement for L\&D policies we want to highlight its potential for facilitating a more thematically structured, and thus hopefully a more constructive, policy and justice discussion.
\end{abstract}

This article is part of a Special Issue on "Climate Justice in Interdisciplinary Research" edited by Christian Huggel, Markus Ohndorf, Dominic Roser, and Ivo Wallimann-Helmer. It is linked to the contribution by Wallimann-Helmer of this special issue.

Christian Huggel

christian.huggel@geo.uzh.ch

1 Department of Geography, University of Zurich, Winterthurerstrasse 190, CH-8057 Zurich, Switzerland

2 Lawrence Berkeley National Laboratory, Berkeley, CA, USA

3 International Arctic Research Center, University of Alaska, Fairbanks, AK 99775-7340, USA

4 Potsdam Institute for Climate Impact Research, Potsdam, Germany 


\section{Introduction}

Impacts of recent climate change on natural and human systems are increasingly detected at the local, regional and global level (Cramer et al. 2014), and include damage to, or loss of, human life and health, ecosystems, and various types of assets. Debates over climate related loss and damage (L\&D) have re-emerged and gained significant traction in international climate policy in recent years, most prominently in the United Nations Framework Convention on Climate Change (UNFCCC) negotiations. Currently, L\&D within the UNFCCC builds on foundations laid at the Conference of Parties (COP) 2010 (COP16) where a work programme on L\&D was established which was consolidated at COP19 with the establishment of the Warsaw International Mechanism for Loss and Damage (WIM) under the Cancun Adaptation Framework (CAF). L\&D has typically been defined as the residual, adverse impacts of climate change beyond what is addressed by mitigation and adaptation (Warner and van der Geest 2013; Okereke et al. 2014). In UNFCCC documentation L\&D is described in relation to a range of negative impacts of climate change and variability, both from extreme weather and slow-onset events (e.g., sea level rise, ocean acidification, glacier retreat and related impacts, land and forest degradation, and loss of biodiversity) (UNFCCC 2012, 2014). Verheyen and Roderick (2008) distinguished three types of L\&D: avoided, unavoided and unavoidable L\&D, where unavoided and unavoidable L\&D corresponds to residual L\&D. Avoided L\&D refers to climate change impacts that are avoided by mitigation and adaptation; unavoided L\&D are those negative impacts that could have been avoided but have not been avoided due to inadequate action; and the third category refers to L\&D that is unavoidable irrespective of how ambitious mitigation and adaptation efforts are. However, in many respects, the definition and framing of L\&D is still unclear, including whether it should be part of the adaptation framework of the UNFCCC or form a separate pillar (Verheyen 2012; Roberts et al. 2014).

An important aspect of these discussions is the type of scientific evidence that corresponding mechanisms could be based on, or more specifically, the question whether and to what extent attribution of impacts to anthropogenic forcing of the climate systems is required or is useful. For adaptation Hulme et al. (2011) and Hulme (2014) argue that decision on financing should be guided by the vulnerability of affected countries and a moral obligation to help developing countries, rather than by attribution. For L\&D, however, James et al. (2014) argue that attribution has been a missing element so far that ought to be included. Here we analyze how useful different types of scientific evidence might be for informing L\&D discussions and potential L\&D policies. We draw on recent progress in attribution research linking observed impacts to anthropogenic climate change (Stone et al. 2013; Cramer et al. 2014; Hansen et al. 2015), including approaches that suggest consideration of a more comprehensive focus on risk when dealing with attribution for climate change related L\&D (Huggel et al. 2013). Note that we do not use the term L\&D strictly in the sense of residual L\&D because of the difficulty to distinguish between observed residual and non-residual L\&D. We first identify different levels of scientific evidence, from simple L\&D observations through to explicit attribution to anthropogenic climate change. To render these categories more tangible for a broader audience, we analyze three case studies (Section 3) and, in Section 4, place these in the context of current discussions concerning L\&D mechanisms or arrangements; the latter involves highlighting both potential and limitations of current attribution research.

The specifics and depth of international climate policy, environmental law and human rights law are beyond the scope of this contribution. Readers should note that this contribution is part of a special issue on climate justice and is accompanied by a companion paper that 
provides more insight into the ethical aspects of climate change L\&D (Wallimann-Helmer, this issue). The target audience is an interdisciplinary scientific community, as well as policy, law and other experts that may have limited insight into more recent progress in detection and attribution of climate change and its impacts.

\section{Scientific evidence concerning L\&D}

In this section we briefly describe three relevant types of evidence concerning climate-related L\&D, characterized by their dependence on observations, understanding and comparative analysis (see also Fig. 1), and complemented by small illustrative examples.

\subsection{L\&D observations}

This simple type of evidence is about the parallel observation of an extreme weather event and of impacts in terms of L\&D. Causal linkage between these two observations can be established with only minimal requirements for the understanding of the underlying mechanisms, and the role of anthropogenic emissions need not be considered. For instance, the unprecedented summer heatwave of 2003 in central Europe was coincident with an increase in the mortality rate far above the seasonal norm in France (Fouillet et al. 2006). Without full evaluation of the relative roles of physiological responses to heat, individual behavior and/or the public health response, the evidence is strong enough to conclude that the simultaneous occurrence of these two rare events was not a coincidence. Importantly for this first category, an explicit consideration of multiple drivers of loss and damage (i.e., hazard, exposure and vulnerability (Huggel et al. 2013)), is not needed, nor is an understanding of the role of anthropogenic emissions.

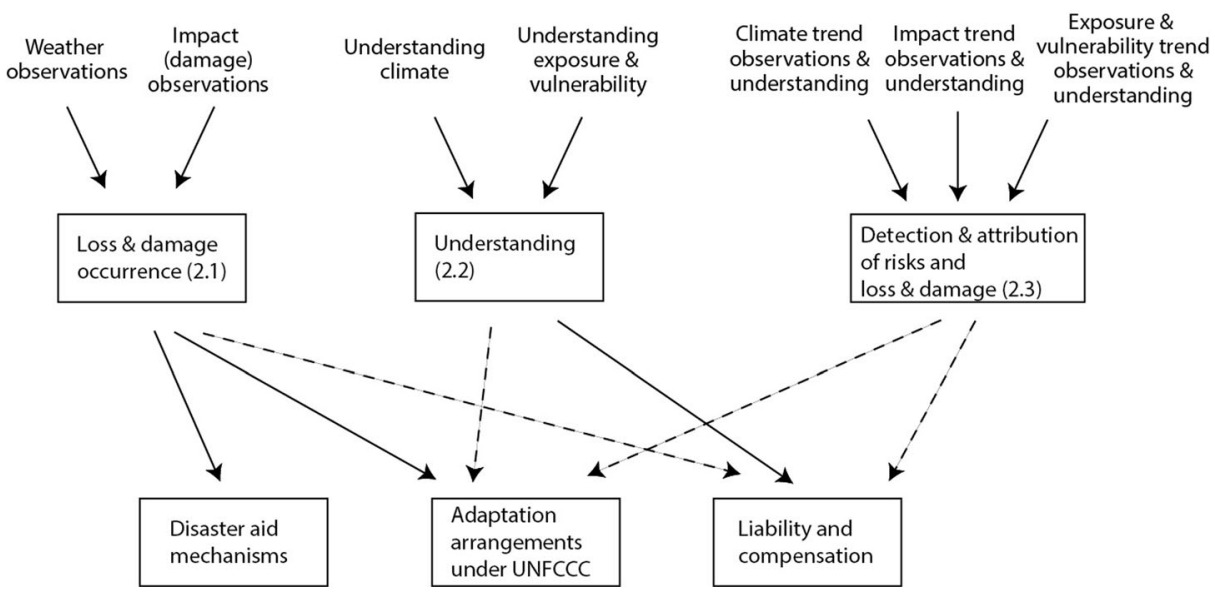

Fig. 1 Schematic illustrating how scientific evidence (middle row) could be linked to three potential dimensions of L\&D concerning policy, law and finance mechanisms (bottom row). The top row specifies the requirements of data, observation and understanding needed for the three different types. Solid arrow lines indicate a (virtually) necessary requirement while dashed arrow lines indicate where it is currently unclear if that type of evidence is required 


\subsection{Understanding causation}

A second category results from understanding how anthropogenic greenhouse gas emissions and the resulting climate change are related to impacts and L\&D, yet without considering direct observational evidence for a particular causal chain (somewhat similar to physical reasoning, cf (Hulme 2014)). The impact of climate change on maize yields can serve as an illustrative example: Increased $\mathrm{CO}_{2}$ in the atmosphere due to human activities is understood to warm the planet, based on the underlying radiative physics. Furthermore, from a wide range of observations, laboratory and modeling studies, there is a reasonable understanding of how maize responds to heat stress (Schlenker and Roberts 2009). Hence, we expect this warming to reduce yields ceteris paribus relative to a counterfactual world without emissions. A relevant characteristic of this category is the absence of direct observational evidence of either a directionally changing climate or a resulting trend in impacts, or both. Thus, this evidence is based on what we understand should be happening, without knowing whether it has actually occurred thus far.

\subsection{Evidence linking emissions to L\&D}

This category, frequently referred to as 'detection and attribution', compares predictions of what our understanding of the various processes dictates should have happened against observations of what has actually happened. It thus combines the previous types 2.1 and 2.2, ensuring that multiple lines of evidence are consistent: documented changes in L\&D; documented changes in the associated climate; and predictions based on modelling of the relevant processes under conditions of both anthropogenic and natural forcing of the climate system (Stone et al. 2013; Hansen et al. 2015). This category is highly demanding as it requires the existence of some form of observational monitoring over a reasonably long period (i.e., several decades), detailed understanding of the relevant processes that relate the impact to climate change and in turn to emissions and other drivers, and the ability to use that understanding to make detailed predictions.

The current state of research on detection and attribution includes studies connecting emissions to various observed climate trends, including extreme weather events (Bindoff et al. 2013), and studies connecting impacts to observed climate trends, but a much smaller and less developed number linking observed impacts all the way to anthropogenic climate change (Cramer et al. 2014). For instance, combining observational data, and climate and hydrological model simulations, Pall et al. (2011) concluded that the probability of occurrence of the type of flooding extent in England in 2000 had substantially increased due to emissions. However, this and other climate attribution studies have not considered the relation of L\&D to anthropogenic emissions. Disaster risk research, on the other hand, examines trends in losses due to extreme weather events, with some research establishing causal relationships with climatic variability (Bouwer 2011; Sander et al. 2013). To satisfy the requirements of this category, however, we would need to consider an attribution framework that identifies the relative contributions of all the risk components (i.e., hazard, exposure, vulnerability, see also IPCC (2014) and Huggel et al. (2013)). Such a treatment of L\&D is currently missing and would imply additional data availability and quality challenges. 


\section{Case studies}

\subsection{9 'Black Saturday' Bushfires in Australia}

In February 2009 the Australian State of Victoria was hit by the "Black Saturday" bushfires that claimed 173 lives and 2133 homes (VBRC 2009). These fires occurred after a decade of unusually low rainfall, and at a time of record high temperatures. Combined, these factors led to some of the most fire prone weather on record (Karoly 2009; Clarke et al. 2013). Thus, the co-occurrence of weather hazard conditions and the observed fire impacts seems an unlikely coincidence, providing strong evidence of the type outlined in Section 2.1.

Temperature, precipitation and humidity are important factors that determine wildfire hazard (Table 1). Victoria is expected to experience warming due to anthropogenic emissions, with the possibility of decreasing precipitation and relative humidity, combining to increase the length and severity of seasonal weather conducive to fire (Reisinger et al. 2014). At the same time, the expansion of urban settlements into suburban areas located within or close to bush land increases the exposure of populations, whereas appropriate fire risk management is known to reduce the loss of lives. Current understanding of type 2.2 leaves unquantified the relative importance of expected anthropogenic climate change in relation to behavioral, social and institutional factors, but it can be informative for designing risk management.

Evidence in line with category 2.3 is available to some extent (Table 1). A moderately increasing trend in fire-prone weather since 1973 has been observed for Victoria (Clarke et al. 2013). This trend appears not to arise simply from a trend in high summer temperatures, but rather an interplay of contributing meteorological factors in both summer and other seasons (Table 1). For the 2009 event, maximum temperature, relative humidity and low rainfall, decisive factors for fire hazard, were exceptional in a way that is consistent with expectations based on anthropogenic emissions (Karoly 2009), but it has yet to be established whether the observed trends are also inconsistent with the absence of anthropogenic emissions.

Damage to buildings due to bushfires increased over the past 80 years, but once the increasing urban settlements (i.e., exposure) over this time is considered, this trend in damage disappears. In very large fires such as in 2009 the exposure of buildings and other structures, i.e., their proximity to fire prone bushland, emerges as the main factor controlling L\&D (Crompton et al. 2010). The extent to which factors such as better fire management, precautionary measures of individual home owners, or improved weather forecasts have reduced L\&D due to individual fires remains subject of debate (Whittaker et al. 2013) (see also Table 1). Overall, then, observational evidence indicates that exposure is a critical driver of long-term trends in $L \& D$, dominating over the influence of anthropogenic climate change.

\subsection{Colombia 2010-2011 floods}

In 2010 and 2011 Colombia was hit by strong floods during a La Niña event, the cold phase of the El Niño Southern Oscillation (ENSO). In Colombia La Niña is typically characterized by intense and prolonged rainfall, high river flows, flooding, and landslides (Restrepo and Kjerfve 2004). More than 4.4 million people in more than 1000 municipalities were affected, with total economic losses amounting to USD6-11bn (UNISDR 2013; Hoyos et al. 2013). The types of L\&D incurred included casualties, destruction of housing and infrastructure, and flooding of agricultural land. These observations fall under the type of evidence described in Section 2.1. 
Table 1 Observed and expected contributors to past bushfire risk over Victoria, Australia. Note that while it is possible to discuss long-term trends for some drivers, for other factors it is only meaningful to discuss the state at the time of the event

\begin{tabular}{|c|c|c|c|}
\hline & Potential driver & Observed changes & Expected changes \\
\hline \multirow[t]{4}{*}{$\begin{array}{l}\text { Climate } \\
\text { drivers of } \\
\text { hazard }\end{array}$} & $\begin{array}{l}\text { High summer } \\
\text { temperatures }\end{array}$ & $\begin{array}{l}\text { Positive trends in maximum } \\
\text { temperature on the continental scale } \\
\text { but less consistent for Victoria } \\
\text { (Alexander et al. 2007; Alexander } \\
\text { and Arblaster 2009) }\end{array}$ & $\begin{array}{l}\text { Increasingly frequent, intense, and } \\
\text { longer duration high temperatures } \\
\text { with anthropogenic emissions } \\
\text { (Reisinger et al. 2014) }\end{array}$ \\
\hline & Precipitation & $\begin{array}{l}\text { Some decrease in autumn totals over } \\
\text { recent decades, but with } \\
\text { background decadal variability } \\
\text { (Alexander et al. 2007; Reisinger } \\
\text { et al. 2014) }\end{array}$ & $\begin{array}{l}\text { Probably decreases in annual totals } \\
\text { with anthropogenic emissions } \\
\text { (Reisinger et al. 2014) }\end{array}$ \\
\hline & $\begin{array}{l}\text { Relative } \\
\text { humidity }\end{array}$ & $\begin{array}{l}\text { Decrease over recent decades in all } \\
\text { seasons but summer (Willett et al. } \\
\text { 2008) }\end{array}$ & $\begin{array}{l}\text { Probably decreases with } \\
\text { anthropogenic emissions (Willett } \\
\text { et al. 2007) }\end{array}$ \\
\hline & Fire weather & $\begin{array}{l}\text { Small increase in a commonly used fire } \\
\text { weather index since } 1973 \text { (Clarke } \\
\text { et al. 2013) }\end{array}$ & $\begin{array}{l}\text { Increases in extreme fire weather } \\
\text { (Hasson et al. 2009; Reisinger et al. } \\
\text { 2014) }\end{array}$ \\
\hline \multirow[t]{3}{*}{$\begin{array}{l}\text { Non-climate } \\
\text { drivers of } \\
\text { hazard }\end{array}$} & $\begin{array}{l}\mathrm{CO}_{2} \\
\text { fertilisation }\end{array}$ & $\begin{array}{l}\text { Unknown (Hovenden and Williams } \\
\text { 2010) }\end{array}$ & $\begin{array}{l}\text { May increase fuel load under } \\
\text { anthropogenic emissions (Williams } \\
\text { et al. 2009) }\end{array}$ \\
\hline & Ignition & Unknown & Unknown \\
\hline & $\begin{array}{l}\text { Fire } \\
\text { management }\end{array}$ & $\begin{array}{l}\text { Improvements in fire-fighting equip- } \\
\text { ment and techniques and weather } \\
\text { forecasting (Nicholls 2011) }\end{array}$ & $\begin{array}{l}\text { Prolonged fire season makes } \\
\text { controlled burning difficult } \\
\text { (Reisinger et al. 2014) }\end{array}$ \\
\hline \multirow[t]{2}{*}{ Exposure } & $\begin{array}{l}\text { Settlement } \\
\text { patterns, } \\
\text { land use, } \\
\text { and land } \\
\text { cover }\end{array}$ & $\begin{array}{l}\text { Increased settlement in high-risk zones } \\
\text { in urban suburbs, increased regula- } \\
\text { tion on vegetation clearing around } \\
\text { properties (VBRC 2009; Buxton } \\
\text { et al. 2011) }\end{array}$ & Increased with population growth \\
\hline & $\begin{array}{l}\text { Fire response } \\
\text { policies }\end{array}$ & $\begin{array}{l}\text { Implementation of "prepare, stay and } \\
\text { defend or leave early" policy may } \\
\text { have exposed more lives (Whittaker } \\
\text { et al. 2013) }\end{array}$ & Unknown \\
\hline \multirow[t]{2}{*}{ Vulnerability } & $\begin{array}{l}\text { Responses of } \\
\text { homeowners }\end{array}$ & $\begin{array}{l}\text { Less important for the large, most } \\
\text { damaging fires (Crompton et al. } \\
\text { 2011; Nicholls 2011) }\end{array}$ & Supposedly no change \\
\hline & Awareness & $\begin{array}{l}\text { High levels of bushfire awareness in } \\
\text { high risk areas, but lower levels in } \\
\text { more suburban locations (Whittaker } \\
\text { and Handmer 2010) }\end{array}$ & Unknown \\
\hline
\end{tabular}

Thermodynamic considerations, and recent climate model runs, suggest a general increase of heavy precipitation events with warming (Christensen et al. 2013) (evidence type 2.2). The understanding of the response of ENSO to emissions is still limited, though. Even though Colombia has experienced considerable economic growth, there remain substantial economic and social inequalities, large poverty pockets, and processes of uncontrolled urbanization. If not counteracted by massive risk reduction and adaptation efforts, such processes result in an increase of (flood) exposure and possibly vulnerability. 
To address detection and attribution (type 2.3) we need much more insight from long-term observational records of hydro-climatic variations, and their possible consistency with theoretical understanding. Independent of changes in ENSO, recent studies have found an increase of heavy precipitation events over much of the continent including Colombia (Skansi et al. 2013). However, the correlation of river discharge in western and central Colombia with ENSO indices is generally high, reaching two thirds of the interannual variability of the Magdalena River draining towards the Caribbean coast Poveda et al. (2011) and Restrepo and Kjerfve (2004), so an understanding of changes in ENSO is needed. While the 2010-2011 La Niña event ranks among the highest in terms of intensity and duration in the one and a half centuries of the historical record (NOAA 2014), data on coupled air-sea feedbacks that control ENSO behavior only date back to the 1970s. Therefore, the evidence is not yet robust enough to assess whether the inter-decadal modulations of ENSO amplitude and spatial patterns are related to warming or are entirely a manifestation of natural variability (Christensen et al. 2013).

Other contributors to risk have been changing over recent decades. Between 1992 and 2009 the annual population growth rate was $1.9 \%$ in Colombia, with growth being substantially stronger in urban areas (2.2\%) than in rural areas (0.9\%) (Álvarez-Berríos et al. 2013). Data on changes in exposure of asset values are lacking but exposure is likely to have paralleled the population increase. UNISDR (2013) analyzed several L\&D metrics for La Niña events since 1970 and found that the number of casualties has declined, which may indicate that changes in vulnerability and/or physical hazard were more important drivers of loss than changes in exposure. There is fairly robust evidence that areas and people affected by the 2010-2011 La Niña event reflect patterns of social vulnerability: over $70 \%$ of affected people were found to live in areas with high rates of poverty and other social vulnerability indicators (UNISDR 2013).

\subsection{Coastal erosion, flooding and other impacts from a diminished sea-ice cover, Alaska}

Arctic summer sea-ice extent and seasonal duration have diminished over the past few decades, with the most pronounced reductions in the North American Arctic (Eicken and Mahoney 2015). In parallel, coastal permafrost in (sub-)Arctic Alaska has warmed by $1-2{ }^{\circ} \mathrm{C}$ (Smith et al. 2010). As a consequence, summer and fall storms are now much more likely to lead to major erosion and flooding events (Vermaire et al. 2013), and shoreline retreat rates have increased two- to three-fold for ice-rich soils (Jones et al. 2009).

General understanding of processes resulting in L\&D (evidence type 2.2) is well developed. At the same time, exposure and vulnerability of Alaska coastal communities have increased substantially in the last century, partly because traditional subsistence lifestyles have been supplanted by fixed village sites. The latter were often determined ad-hoc with little community input, mostly based on siting of major infrastructure and hence convenient beach or river bank access (Maldonado et al. 2013). Such exposure trends and a lack of historical or long data records in many of these locations, complicate the establishment of causal (type 2.2) or even statistical links (type 2.3) related to sudden or slow onset L\&D events. However, in light of sparse instrumental records, analysis of relevant trends in risk drivers may be supported by local and indigenous knowledge, which can serve as an important source of information if the social and cultural context is adequately understood (Jurt et al., this issue). 
Traditional environmental knowledge (Krupnik et al. 2010) and geophysical studies (Barnhart et al. 2014) point toward links between atmospheric warming, sea ice reductions, permafrost thaw, storm activity and increasing risks (summarized in Fig. 2). However, the specific interactions among these four environmental processes controlling L\&D and increases in slow-onset hazards (Fig. 2) are difficult to quantify, and hence confound full detection and attribution of anthropogenic factors in terms of type 2.3 evidence. The Alaska section of the U.S. National Climate Assessment reflects this state of the science, with high confidence in the projected long-term impacts of climate change but details required for L\&D assessments lacking (Chapin et al. 2014). For sea ice, a combination of observational evidence (Notz and Marotzke 2012) and modeling studies (Wang and Overland 2012) indicates that emissions of greenhouse gases, black carbon, and other aerosols almost certainly have contributed to the observed long-term trend in reduction of summer ice extent by affecting the surface energy budget (Serreze and Barry 2011). On decadal timescales natural variability can still have some influence on sea ice changes (Kay et al. 2011). Nevertheless, attribution studies and evaluation of type 2.3 evidence are disproportionately relevant in the study of L\&D in high-latitude regions such as Alaska where the effects of Arctic amplification of climate change (Serreze and Barry 2011) come to bear.

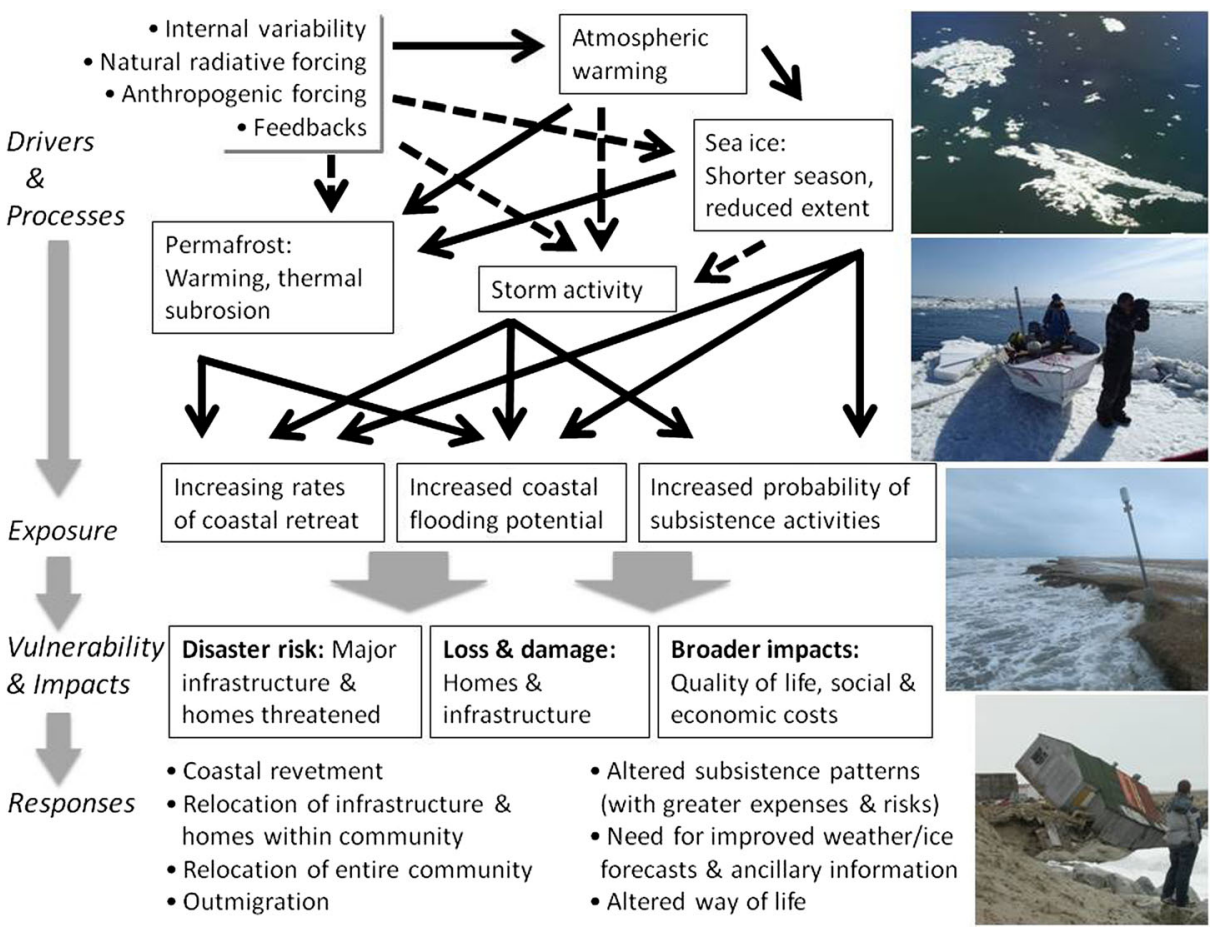

Fig. 2 Schematic depiction of key drivers and processes controlling hazards and risks for coastal communities in Arctic and western Alaska, their linkages and their impact on human activities relevant in the context of rapid climate change. Dashed arrows indicate a level of understanding commensurate with types of scientific evidence 2.1 and 2.2 (Fig. 1), whereas solid arrows indicate higher certainty with respect to full detection and attribution (category 2.3, for details see text). Grey arrows outline causal chains relevant for determination of L\&D and development of policy and legal mechanisms 


\section{Implications for climate justice and policy}

Section 3 provided a small sample of examples for L\&D and related causes in various contexts. Based on these real-world case studies, we have seen that the reality of the role of weather and climate change in L\&D is typically complex and sometimes goes beyond the categories of scientific evidence as outlined in Section 2. However, we also recognize that such a distinction of different types of scientific evidence, which has been missing in the discussion, is useful to break the complexity down to more tangible portions that can be addressed by, and require, distinct methodological approaches and data.

In the following, we link the findings of Sections 2 and 3 to climate policies with associated questions of justice, and try to clarify some of the potential and limitations of attribution analysis in this context. For this purpose, we suggest to distinguish three potential lines of L\&D concerning policy, law and finance mechanisms: (i) disaster aid, (ii) arrangements under the UNFCCC adaptation framework, and (iii) liability and compensation, including human rights law and environmental law (cf. also Fig. 1). While a major simplification, this categorization broadly follows existing mechanisms as well as the currently open question whether L\&D should be considered within the UNFCCC adaptation framework. For a more in-depth perspective into these mechanisms we refer to the corresponding literature, including some contributions in this special issue.

For disaster aid, evidence of type 2.1 was relevant for all cases analyzed from Colombia, Alaska and Australia. In all three cases disaster aid was predominantly or exclusively domestic, although Colombia is also a recipient of important international disaster risk and adaptation financing. Typically it is simply observed L\&D that triggers disaster aid mechanisms. In Australia, during and following the fires, local, provincial, and national institutions provided aid and relief to people impacted by the fires, coupled afterward by AUD1.2 billion in insurance claims (VBRC 2009). The case of Alaska is somewhat less clear as slow-onset and sudden-onset hazards overlap, and present funding support is mostly subsumed under categories of disaster response and emergency preparedness. Damages during recent storms in fall 2013 were on the order of up to USD1M at the community level (Hollander and Kelly 2013), with federal and state disaster aid covering a significant portion of these costs as a result of disaster declarations. Overall, it seems that evidence of type 2.1 is sufficient for disaster aid for climate related L\&D, with no specific role for attribution (2.3). This is fully in line with the humanitarian principle that relief should be provided where it is most needed in terms of saving lives and reducing human suffering, irrespective of the causes of the disaster.

Next we focus on international arrangements within the UNFCCC and specifically under the Cancun Adaptation Framework (CAF) which is linked to a number of financing mechanisms such as the Adaptation Fund (AF), the Special Climate Change Fund (SCCF), the Least Developed Countries Fund (LDCF), the Global Environmental Facility (GEF) or the Green Climate Fund (GCF). At the current state of UN negotiations the L\&D mechanism is located within the CAF. However, whether L\&D should be framed within or outside the existing adaptation framework is subject to political debate and negotiations. Current adaptation arrangements aim to strengthen adaptive capacity and resilience, and reduce vulnerabilities, while for L\&D UNFCCC documents underline the importance to enhance data and understanding of how L\&D are associated with climate change impacts, and promote corresponding risk management approaches (Hulme et al. 2011; UNFCCC 2014). If we consider these objectives, scientific evidence of type 2.1 may be useful in terms of justification of adaptation financing, but type 2.2 is substantially more important for improving understanding of L\&D 
and associated risks, and thus enhancing adaptation efforts and investments. As Hulme et al. (2011) and Hulme (2014) pointed out, attribution to anthropogenic emissions is not necessary for adaptation. However, by confronting our understanding (2.2) with observations (2.3) we gain a calibrated evaluation of both the absolute and relative contributors to $L \& D$, and thus of the urgency and priority of various adaptation options.

From the case studies in Section 3 we can glean how the different types of scientific evidence may be related to, and inform, adaptation associated with L\&D. For the case of Colombia, the understanding of the multiple factors contributing to flood related L\&D is an important basis for planning and implementing adaptation and risk reduction measures, but the lack of evidence of a major role of anthropogenic climate change means that, sensu stricto, these measures would not necessarily be carried out under the flag of climate change adaptation. In Australia, the summer 2009 bushfires triggered a vigorous discussion on the role of anthropogenic climate change in wildfire-related $L \& D$, leading to studies examining the various contributors to wildfire risk following both the approaches described in Sections 2.2 (understanding) and 2.3 (attribution) (see Table 1); it remains to be seen whether and how adaptation approaches are informed by these studies. Even though in Alaska most of the support so far falls under the umbrella of domestic disaster and emergency aid, communitylevel government in Alaska points to the recurrence of such disasters and potential causal linkages between climate change and coastal threats (David 2014), highlighting the need to go beyond immediate repair into building adaptive capacity and resilience in anticipation of future climate change.

We now turn to liability and compensation in relation to L\&D and environmental and human rights law. Without going into detail, we may summarize that current lines of discussion refer to tort liability and human rights, among others, with some scholars focusing on domestic law (e.g., (Grossman 2003; Posner 2007), and others on international law (e.g., (Verheyen and Roderick 2008; McInerney-Lankford et al. 2011)). The views are manifold as to which legal mechanisms could apply or which hurdles might be encountered, such as practical difficulties of the application of the no-harm rule even though it is well established in international law (Weisbach 2012), or limitations and missing clarity of the application of extraterritoriality in human rights law (McInerney-Lankford et al. 2011). However, tort liability and compensation of L\&D is not only a matter of law but also of policy, and essentially of climate justice. If we consider a scenario where L\&D would be framed outside current adaptation mechanisms of the UNFCCC, this presumably implies a need to address compensation; and it is thought that the negotiations of a new climate agreement need to consider compensation (Surminski and Lopez 2014). Discussions on mechanisms of compensation may involve questions of causation, and the variation (or deviation) from baseline conditions (Verheyen and Roderick 2008). The information that attribution (2.3) can contribute to compensation discussions or policy depends on (i) the type of impact and L\&D (i.e., processes); (ii) availability and quality of observations of the multitude of contributors of the outcome; and (iii) understanding of drivers of L\&D (2.2). A full-scale quantitative attribution exercise of all risk components may currently be elusive, but providing guidance on the relative contribution of hazard (possibly including effects of anthropogenic climate change), exposure and vulnerability would be valuable. Nevertheless, what kind of evidence will actually be required by either climate policy or at court is difficult to foresee.

In both the Alaska and Australia cases tort liability and compensation have been an issue, and it is interesting to briefly look how this has been tackled. In northwestern Alaska, the Native Village and City of Kivalina alleged that greenhouse gas emissions have resulted in 
warming and sea-ice reduction which in turn have driven erosion threatening the village site, and claimed damages from hydrocarbon and energy producers (Shearer 2011). This lawsuit was ultimately dismissed by court (U.S. Superior Court 2012), without the science of attribution entering into the legal finding. Current discussions and efforts in Alaska focus on either relocation of communities or on risk reduction measures such as coastal revetments or infrastructure hardening, which are meant to buy time until the longer-term adaptation measures such as community relocation can be implemented. However, due to the magnitude of the effort, with relocation costs per village estimated in the tens to few hundred millions U.S. dollars, progress towards relocation has been slow, with only one community having made significant headway (GAO 2009; Maldonado et al. 2013). Nonetheless, the Arctic is of particular interest in an attribution context because Arctic amplification of global climate change may lower the evidentiary threshold for the establishment of both causal event chains and climate trends, with potential implications on liability and compensation.

In Australia, in July 2014, a group of plaintiffs of the 'Black Saturday' disaster reached a settlement of a record high payment of AUD497.7 million with electricity providers and a government department for alleged inadequate maintenance of power lines and fire prevention measures. The case emerged because an ageing power line was found to have triggered the bushfires. The manner in which other contributors to fire risk might be considered in this sort of 'triggering causation' proof remains to be determined.

A final point with additional implications for climate justice concerns the monitoring efforts necessary to support the respective scientific evidence (cf. Fig. 1). The type of evidence described in Section 2.1 places a low burden of monitoring and effort on those impacted. This type of evidence does not require impacted communities to have had the premonition and resources for implementation of a monitoring system well in advance of impacts whose processes are well understood. In contrast, while the evidence based on attribution (type 2.3) is most complete in linking the hazard component of L\&D (e.g., extreme weather events) to emissions, it also places an extremely heavy monitoring burden on those affected. Lowincome countries which so far have seen the highest losses in terms of casualties due to extreme weather events (Strömberg 2007) typically have not had the means to have deployed long-term monitoring systems, and other serendipitous proxies (e.g., lake sediment cores) may be lacking. How relevant the burden of monitoring actually is also depends on where the burden of proof lies. Verheyen and Roderick (2008), based on evidence from environmental law cases, argue that the precautionary principle reverses the burden of proof. If this was the case developing countries would no longer bear the burden of monitoring, for instance in order to seek compensation. On the other hand, there might be issues of territoriality if richer nations felt compelled to demand unimpeded access to monitoring within developing countries.

\section{Conclusions}

In this study we analyzed different types of scientific evidence of the role of weather and climate change in L\&D and of their respective potential and limitations in view of informing different L\&D policies. The simplest one comprises parallel observations of extreme weather events and L\&D (2.1), typically a trigger of disaster aid. Understanding of causation (2.2) is more complex and multi-disciplinary, involving climate, hazards, risks, and social and economic sciences. It has the potential to guide and support adaptation and risk reduction. Understanding extended by comparison against observational evidence of changes in climate 
hazard, exposure and vulnerability (2.3) sets the highest bar, but also provides the most complete set of information to support adaptation, risk reduction and L\&D policies. Hence, rather than suggesting that attribution is a necessary requirement for L\&D policies we want to highlight its potential for facilitating a more thematically structured, and thus hopefully a more constructive, policy and justice discussion. To what extent policy or courts are willing to make use of this potential remains an open part of this discussion.

Acknowledgments The authors would like to thank Ivo Wallimann-Helmer for discussions which improved the focus of the paper. Collaboration and discussions with colleagues of the IPCC WGII AR5, chapter 18, have set an important basis for this paper. $\mathrm{CH}$ was supported by strategic funds by the Executive Board and Faculty of Science of the University of Zurich. DAS was supported by the U.S. Department of Energy, Office of Science, Office of Biological and Environmental Research's Regional and Global Climate Modelling Program under contract number DE-AC02-05CH11231. GH was supported by the German Federal Ministry of Education and Research. We appreciate the insightful comments by Mike Hulme and two anonymous reviewers as well as those of the guest editors, Dominic Roser and Markus Ohndorf, which helped restructuring and improving the paper. We also extend thanks to André Wehrli for discussions on loss and damage.

\section{References}

Alexander LV, Arblaster JM (2009) Assessing trends in observed and modelled climate extremes over Australia in relation to future projections. Int J Climatol 29:417-435. doi:10.1002/joc.1730

Alexander LV, Hope P, Collins D et al (2007) Trends in Australia's climate means and extremes: a global context. Aust Meteorol Mag 56:1-18

Álvarez-Berríos NL, Parés-Ramos IK, Aide TM (2013) Contrasting patterns of urban expansion in Colombia, Ecuador, Peru, and Bolivia between 1992 and 2009. AMBIO 42:29-40. doi:10.1007/s13280-012-0344-8

Barnhart KR, Anderson RS, Overeem I et al (2014) Modeling erosion of ice-rich permafrost bluffs along the Alaskan Beaufort Sea coast. J Geophys Res Earth Surf 119:1155-1179. doi:10.1002/2013JF002845

Bindoff NL, Stott PA, AchutaRao KM, Allen MR, Gillett N, Gutzler D, Hansingo K, Hegerl G, Hu Y, Jain S, Mokhov II, Overland J, Perlwitz J, Sebbari R, Zhang X (2013) Detection and attribution of climate change: from global to regional. In: Stocker TF, Qin D, Plattner G-K, Tignor M, Allen SK, Boschung J, Nauels A, Xia Y, Bex V, Midgley PM (eds) Climate change 2013: the physical science basis. Contribution of Working Group I to the Fifth Assessment Report of the Intergovernmental Panel on Climate Change. Cambridge University Press, Cambridge, pp 867-952

Bouwer LM (2011) Have disaster losses increased due to anthropogenic climate change? Bull Am Meteorol Soc 92:39-46. doi:10.1175/2010BAMS3092.1

Buxton M, Haynes R, Mercer D, Butt A (2011) Vulnerability to bushfire risk at Melbourne's urban fringe: the failure of regulatory land use planning. Geogr Res 49:1-12. doi:10.1111/j.1745-5871.2010.00670.x

Chapin FS III, Trainor SF, Cochran P et al (2014) Ch. 22: Alaska. Climate change impacts in the United States: the third national climate assessment. In: Melillo JM, Richmond TC, Yohe GW (eds) U.S. global change research program. pp 514-536

Christensen JH, Krishna Kumar K, Aldrian E, An S-I, Cavalcanti IFA, de Castro M, Dong W, Goswami P, Hall A, Kanyanga JK, Kitoh A, Kossin J, Lau N-C, Renwick J, Stephenson DB, Xie S-P, Zhou T (2013) Climate phenomena and their relevance for future regional climate change. In: Stocker TF, Qin D, Plattner G-K, Tignor M, Allen SK, Boschung J, Nauels A, Xia Y, Bex V, Midgley PM (eds) Climate change 2013: the physical science basis. Contribution of Working Group I to the Fifth Assessment Report of the Intergovernmental Panel on Climate Change. Cambridge University Press, Cambridge, pp 1217-1308

Clarke H, Lucas C, Smith P (2013) Changes in Australian fire weather between 1973 and 2010. Int J Climatol 33: 931-944. doi:10.1002/joc.3480

Cramer W, Yohe G, Auffhammer M et al (2014) Detection and attribution of observed impacts. In: Field CB, Barros V, Dokken DJ, Mastrandrea MD, Mach KJ (eds) Climate change 2014: impacts, adaptation, and vulnerability. Part A: Global and Sectoral Aspects. Contribution of Working Group II to the Fifth Assessment Report of the Intergovernmental Panel on Climate Change. Cambridge University Press, Cambridge, pp 979-1037 
Crompton RP, McAneney KJ, Chen K et al (2010) Influence of location, population, and climate on building damage and fatalities due to Australian bushfire: 1925-2009. Weather Clim Soc 2:300-310. doi:10.1175/ 2010WCAS1063.1

Crompton RP, McAneney KJ, Chen K et al (2011) Reply. Weather Clim Soc 3:63-66. doi:10.1175/WCAS-D-1100002.1

David M (2014) Oral testimony of Mary David, Executive Vice President Kawerak, Inc. U.S. Senate Committee on Indian Affairs, Testimony 30 July 2014, 13 pp

Eicken H, Mahoney AR (2015) In: Ellis J, Sherman D, Ellis J, Sherman D (eds) Coastal and marine hazards, risks and disasters. Elsevier, Oxford, pp 381-401

Fouillet A, Rey G, Laurent F et al (2006) Excess mortality related to the August 2003 heat wave in France. Int Arch Occup Environ Health 80:16-24. doi:10.1007/s00420-006-0089-4

GAO (Government Accountability Office) (2009) Alaska native villages: limited progress has been made on relocating villages threatened by flooding and erosion. U.S. Government Accountability Office, Washington, D.C.

Grossman DA (2003) Warming up to a not-so-radical idea: tort-based climate change litigation. Columbia J Environ Law 28:1

Hansen G, Stone D, Auffhammer M et al (2015) Linking local impacts to changes in climate-a guide to attribution. Reg Environ Change. doi:10.1007/s10113-015-0760-y

Hasson A, Mills G, Timbal B, Walsh K (2009) Assessing the impact of climate change on extreme fire weather events over southeastern Australia. Clim Res 39:159-172. doi:10.3354/cr00817

Hollander Z, Kelly D (2013) Storm leaves trail of damage in western Alaska coastal villages. Anchorage Daily News, 11 Nov 2013. Anchorage Daily News

Hovenden MJ, Williams AL (2010) The impacts of rising CO2 concentrations on Australian terrestrial species and ecosystems. Austral Ecol 35:665-684. doi:10.1111/j.1442-9993.2009.02074.x

Hoyos N, Escobar J, Restrepo JC et al (2013) Impact of the 2010-2011 La Niña phenomenon in Colombia, South America: the human toll of an extreme weather event. Appl Geogr 39:16-25. doi:10.1016/j.apgeog. 2012.11.018

Huggel C, Stone D, Auffhammer M, Hansen G (2013) Loss and damage attribution. Nat Clim Chang 3:694-696. doi:10.1038/nclimate1961

Hulme M (2014) Attributing weather extremes to "climate change" a review. Prog Phys Geogr 38:499-511. doi: $10.1177 / 0309133314538644$

Hulme M, O’Neill SJ, Dessai S (2011) Is weather event attribution necessary for adaptation funding? Science 334:764-765. doi:10.1126/science. 1211740

IPCC (2014) Climate change 2014: impacts, adaptation, and vulnerability. Part A: global and sectoral aspects. Contribution of Working Group II to the Fifth Assessment Report of the Intergovernmental Panel on Climate Change. Cambridge University Press, Cambridge

James R, Otto F, Parker H et al (2014) Characterizing loss and damage from climate change. Nat Clim Chang 4: 938-939. doi:10.1038/nclimate2411

Jones BM, Arp CD, Beck RA et al (2009) Erosional history of Cape Halkett and contemporary monitoring of bluff retreat, Beaufort Sea coast, Alaska. Polar Geogr 32:129-142

Karoly D (2009) The recent bushfires and extreme heat wave in southeast Australia. Bull Aust Meteorol Oceanogr Soc 22:10-13

Kay JE, Holland MM, Jahn A (2011) Inter-annual to multi-decadal Arctic sea ice extent trends in a warming world. Geophys Res Lett 38, L15708. doi:10.1029/2011GL048008

Krupnik I, Aporta C, Gearheard S et al (2010) SIKU: knowing our ice-documenting Inuit sea ice knowledge and use. Springer, New York

Maldonado JK, Shearer C, Bronen R et al (2013) The impact of climate change on tribal communities in the US: displacement, relocation, and human rights. Clim Chang 120:601-614. doi:10.1007/s10584-013-0746-Z

McInerney-Lankford S, Darrow M, Rajamani L (2011) Human rights and climate change: a review of the international legal dimensions. World Bank Publications, Washington D.C.

Nicholls N (2011) Comments on "influence of location, population, and climate on building damage and fatalities due to Australian bushfire: 1925-2009.”. Weather Clim Soc 3:61-62. doi:10.1175/WCAS-D-1005001.1

NOAA (2014) Multivariate ENSO Index (MEI). National Oceanic and Atmospheric Administration (NOAA), Earth System Research Laboratory, Boulder

Notz D, Marotzke J (2012) Observations reveal external driver for Arctic sea-ice retreat. Geophys Res Lett 39, L08502. doi:10.1029/2012GL051094

Okereke C, Baral P, Dagnet Y (2014) Options for adaptation and loss \& damage in a 2015 climate agreement. Working Paper. Agreement for Climate Transformation 2015 (ACT15), Washington D.C., p 19 pp 
Pall P, Aina T, Stone DA et al (2011) Anthropogenic greenhouse gas contribution to flood risk in England and Wales in autumn 2000. Nature 470:382-385. doi:10.1038/nature09762

Posner EA (2007) Climate change and international human rights litigation: a critical appraisal. Social Science Research Network, Rochester

Poveda G, Álvarez DM, Rueda ÓA (2011) Hydro-climatic variability over the Andes of Colombia associated with ENSO: a review of climatic processes and their impact on one of the Earth's most important biodiversity hotspots. Clim Dyn 36:2233-2249. doi:10.1007/s00382-010-0931-y

Reisinger A, Kitching RL, Chiew F et al (2014) Australasia. In: Barros VR, Field CB, Dokken DJ et al (eds) Climate change 2014: impacts, adaptation, and vulnerability. Part B: Regional Aspects. Contribution of Working Group II to the Fifth Assessment Report of the Intergovernmental Panel of Climate Change. Cambridge University Press, Cambridge, pp 1371-1438

Restrepo JD, Kjerfve B (2004) The Pacific and Caribbean Rivers of Colombia: water discharge, sediment transport and dissolved loads. In: Lacerda PLD, de Santelli PRE, Duursma PEK, Abrão PJJ (eds) Environmental geochemistry in tropical and subtropical environments. Springer, Berlin, pp $169-187$

Roberts E, van der Geest K, Warner K, Andrei S (2014) Loss and damage: when adaptation is not enough. Environ Dev 11:219-227. doi:10.1016/j.envdev.2014.05.001

Sander J, Eichner JF, Faust E, Steuer M (2013) Rising variability in thunderstorm-related U.S. losses as a reflection of changes in large-scale thunderstorm forcing. Weather, Climate, and Society 130409112301007. doi:10.1175/WCAS-D-12-00023.1

Schlenker W, Roberts MJ (2009) Nonlinear temperature effects indicate severe damages to U.S. crop yields under climate change. PNAS 106:15594-15598. doi:10.1073/pnas.0906865106

Serreze MC, Barry RG (2011) Processes and impacts of Arctic amplification: a research synthesis. Glob Planet Chang 77:85-96. doi:10.1016/J.Gloplacha.2011.03.004

Shearer C (2011) Kivalina: a climate change story. Haymarket Books, Chicago

Skansi MM, Brunet M, Sigró J et al (2013) Warming and wetting signals emerging from analysis of changes in climate extreme indices over South America. Glob Planet Chang 100:295-307. doi:10.1016/j.gloplacha. 2012.11.004

Smith SL, Romanovsky VE, Lewkowicz AG et al (2010) Thermal state of Permafrost in North America: a contribution to the international polar year. Permafr Periglac 21:117-135. doi:10.1002/Ppp.690

Stone D, Auffhammer M, Carey M et al (2013) The challenge to detect and attribute effects of climate change on human and natural systems. Clim Chang 121:381-395. doi:10.1007/s10584-013-0873-6

Strömberg D (2007) Natural disasters, economic development, and humanitarian aid. J Econ Perspect 21:199_ 222

Surminski S, Lopez A (2014) Concept of loss and damage of climate change - a new challenge for climate decision-making? A climate science perspective. Clim Dev 1-11. doi:10.1080/17565529.2014.934770

U.S. Superior Court (2012) Opinion No. 09-17490 (Native Village of Kivalina; City of Kivalina v. ExxonMobil Corporation et al.). U.S. Courts of Appeals for the Ninth Circuit, San Francisco

UNFCCC (2012) A literature review on the topics in the context of thematic area 2 of the work programme on loss and damage: A range of approaches to address loss and damage associated with the adverse effects of climate change. United Nations Framework Convention on Climate Change (UNFCCC). Subsidiary Body for Implementation (SBI), FCCC/SBI/2012/INF.14

UNFCCC (2014) Report of the Executive Committee of the Warsaw International Mechanism for Loss and Damage associated with Climate Change Impacts. United Nations Framework Convention on Climate Change (UNFCCC).Subsidiary Body for Scientific and Technological Advice (SBSTA), Subsidiary Body for Implementation (SBI), FCCC/SB/2014/4

UNISDR (2013) La ruralidad, la fragilidad urbana y el fenómeno La Niña en Colombia, 1970-2011. Background Paper prepared for the Global Assessment Report on Disaster Risk Reduction 2013. Corporación OSSO, Cali

VBRC (Victorian Bushfires Royal Commission) (2009) Final Report. Victorian Bushfires Royal Commission. Parliament of Victoria, Victoria, Australia

Verheyen R (2012) Tackling Loss \& Damage-A New Role for the Climate Regime

Verheyen R, Roderick P (2008) Beyond Adaptation-The legal duty to pay compensation for climate change damage. WWF-UK, Panda House, Weyside Park Godalming, Surrey GU7 1XR

Vermaire JC, Pisaric MFJ, Thienpont JR et al (2013) Arctic climate warming and sea ice declines lead to increased storm surge activity. Geophys Res Lett. doi:10.1002/Grl.50191

Wang MY, Overland JE (2012) A sea ice free summer Arctic within 30 years: an update from CMIP5 models. Geophys Res Lett. doi:10.1029/2012gl052868

Warner K, van der Geest K (2013) Loss and damage from climate change: local-level evidence from nine vulnerable countries. Int J Glob Warm 5:367-386. doi:10.1504/IJGW.2013.057289 
Weisbach DA (2012) Negligence, strict liability, and responsibility for climate change. Iowa Law Rev 97:521565

Whittaker J, Handmer J (2010) Community bushfire safety: a review of post-black saturday research. Aust J Emerg Manag 25:7-13

Whittaker J, Haynes K, Handmer J, McLennan J (2013) Community safety during the 2009 Australian "Black Saturday" bushfires: an analysis of household preparedness and response. Int J Wildland Fire 22:841-849

Willett KM, Gillett NP, Jones PD, Thorne PW (2007) Attribution of observed surface humidity changes to human influence. Nature 449:710-712

Willett KM, Jones PD, Gillett NP, Thorne PW (2008) Recent changes in surface humidity: development of the HadCRUH dataset. J Clim 21:5364-5383. doi:10.1175/2008JCLI2274.1

Williams RJ, Bradstock RA, Cary GJ et al (2009) Interactions between climate change, fire regimes and biodiversity in Australia. Department of Climate Change and Department of the Environment, Heritage and Arts, Canberra 